\title{
PERFORMANCE OF POWER PLANT COOLING LAKES IN POLAND
}

\begin{abstract}
Polish Institute of Meteorology and Water Management conducted a study to determine the effectiveness of cooling lakes in dissipating the waste heat from steam electric generating stations. The study was conducted at two locations: 1 . the Konin Lake Complex, which consists of five lakes of a total surface area of $12.35 \mathrm{~km}^{2}$ to provide cooling for two power plants with a total electrical capacity of $1783 \mathrm{MWe}$; 2 . Rybnik Power station ( $800 \mathrm{MWe}$ ), which uses an impoundment of the Ruda River with a surface area of $4.65 \mathrm{~km}^{2}$. Meteorological and power plant operating data were collected and analyzed to determine the rate of heat exchange at the cooling-lake surface. Over an annual cycle, the rate of heat exchange for both locations was approximately $16 \mathrm{kcal} / \mathrm{m}^{2}-\mathrm{hr}-{ }^{\circ} \mathrm{C}$. The values determined for the Polish locations compare favourably with empirical data reported in the technical literature.
\end{abstract}

\section{INTRODUCTION}

Data were collected by the Institute of Meteorology and Water Management on power plant operation and cooling-lake performance at two coal-fired steam electric generating complexes. Figure 1 indicates the location of these facilities. The Konin Lake Complex, located in central Poland, involves five lakes and two power plants with a total capacity of almost 1800 MWe. Rybnik is an 800 MWe plant in southern Poland near the Czechoslovakian border.

* Head, Water Management Division, Institute of Meteorology and Water Management, 01-673 Warsaw, ul. Podleśna 61, Poland.

** Chemical Processes Branch, Industrial Environmental Research Laboratory, EPA, Research Triangle Park, North Carolina 27711. 


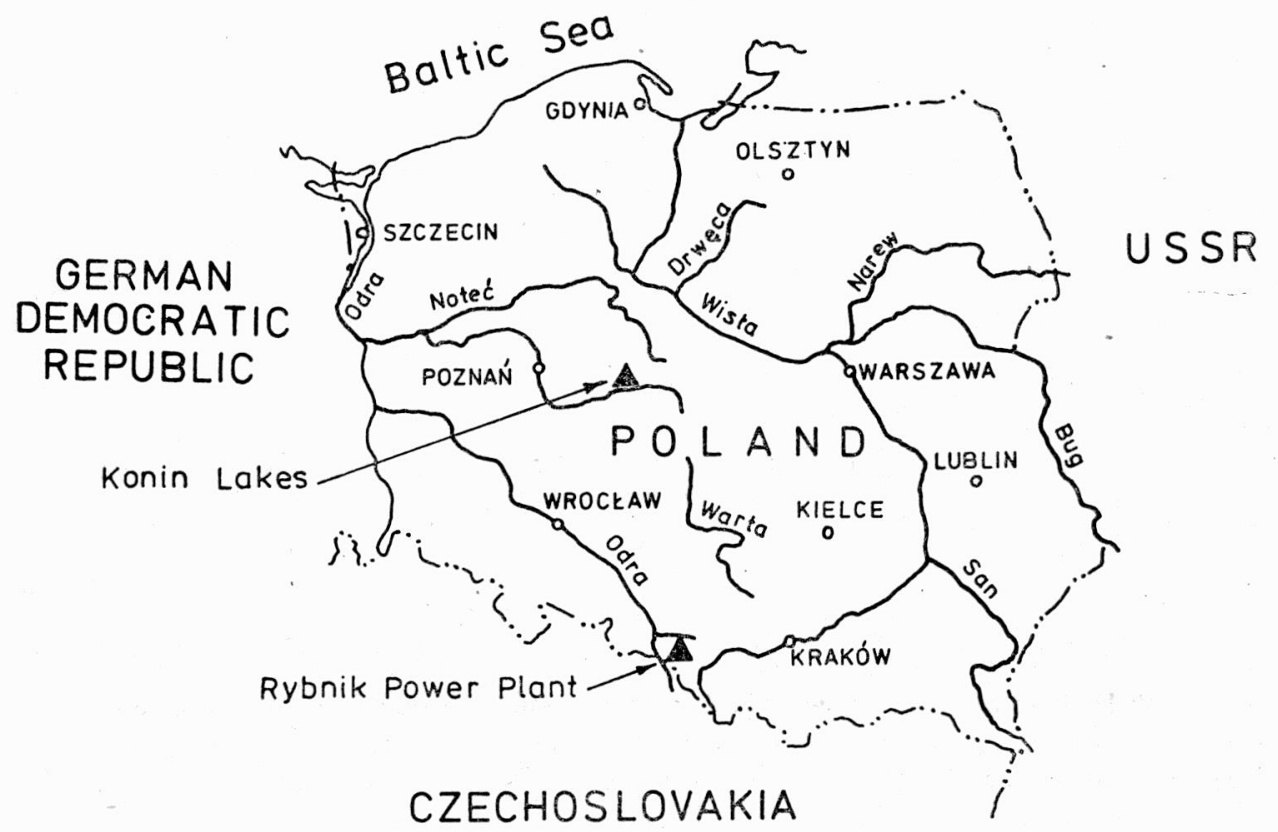

Fig. 1. Location of Rybnik Power Plant and Konin Lakes

Rys. 1. Polożenie Elektrowni Rybnickiej i Jezior Konińskich

\section{KONIN LAKE COMPLEX}

Power generation at Konin began in 1958 with the initial unit of the Konin Power Plant. By 1965, the plant had reached its present capacity of 583 MWe. In 1967, the first 200 MWe unit of the Pątnów Plant came on line, and by 1970 it reached a capacity of

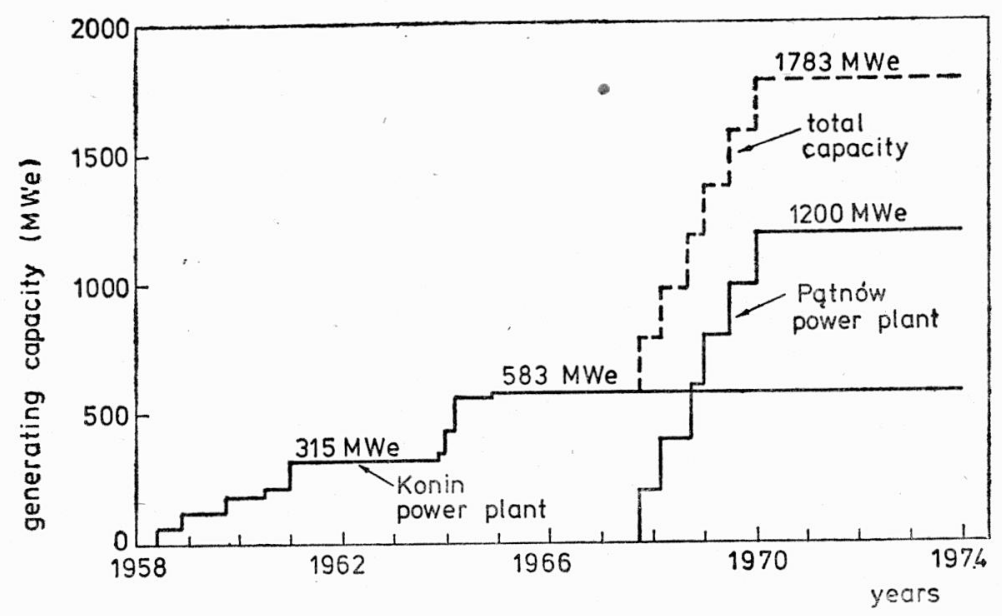

Fig. 2. Konin Lakes power station - capacity history

Rys. 2. Hydroelektrownia na Jeziorach Konińskich - wydajność i historia 
1200 MWe. Figure 2 shows how the capacity of the two multi-unit plants increased from 1958 to 1974. The Pątnów Plant increased its capacity in 1974; however, the results presented here are based on data collected prior to 1974.

As the Konin and Pątnów Plants were put on line, the five Konin Lakes were utilized in a systematic way to dissipate the waste heat in the cooling water. Figure 3 provides an

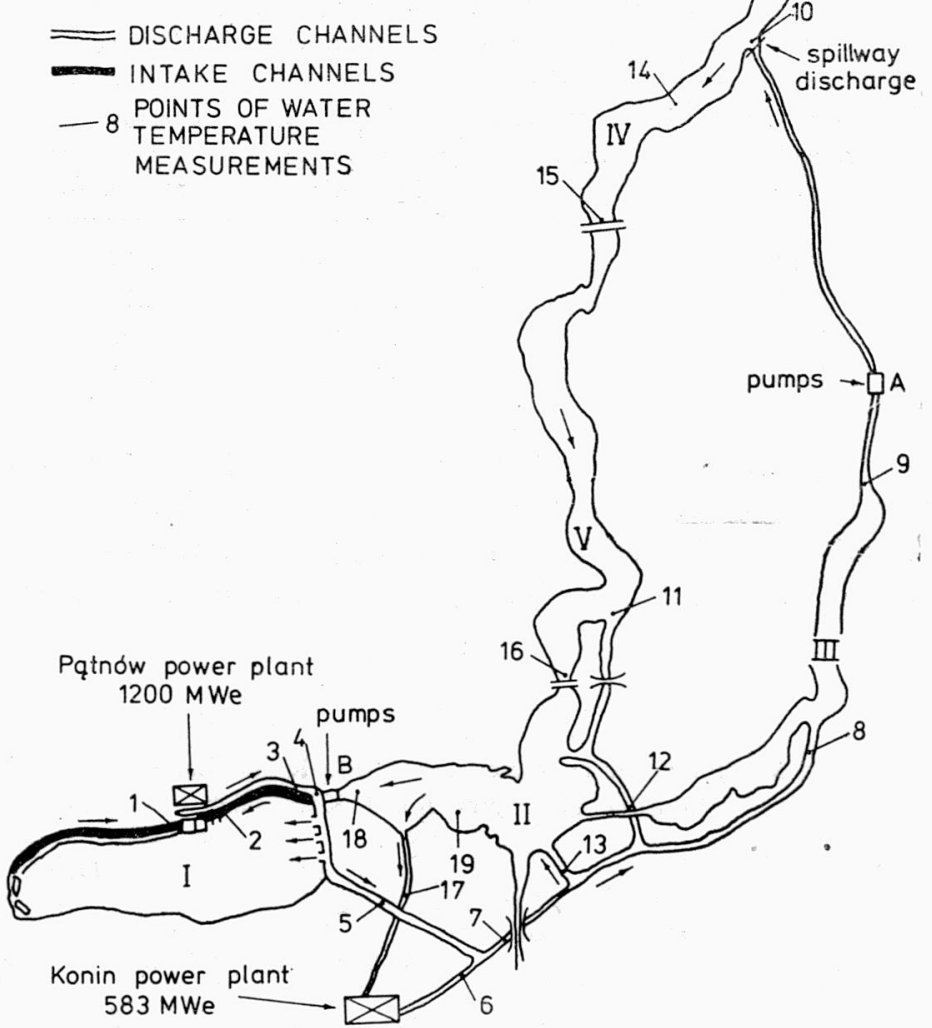

Fig. 3. Konin Lakes cooling system

Rys. 3. System chłodzący Jezior Konińskich

overall view of how the Konin Lakes are tied together to act as cooling lakes for the two power plants. Until 1964, only Pątnowskie Lake was used to handle the waste heat from the 315 MWe capacity of the Konin Plant (fig. 2). In 1964, when the Konin Plant was expanded to 583 MWe, Licheńskie Lake was added to the cooling system. The Pątnów Plant was added to the complex in 1967, and Gosławskie Lake was used to handle the first $600 \mathrm{MWe}$. In 1959, the Pątnów Plant began expanding from 600 to $1200 \mathrm{MWe}$, and the cooling circuit for the combined plants extended to all five lakes, adding Ślesińskie Lake and Wąsowsko-Mikorzyńskie Lake. The cooling water flow in the lake system is 
gravitational, except for two locations where pump stations are employed. The first pump station is located on the Licheńskie-Ślesińskie channel (point A in fig. 3) and has a capacity of $23.6 \mathrm{~m}^{3} / \mathrm{sec}$; the second pump station is installed on Pątnowskie Lake at the Pątnów Plant intake (point B in fig. 3) with a capacity of $25.1 \mathrm{~m}^{3} / \mathrm{sec}$. Table 1 provides data related to power plant capacity and cooling-lake surface area for the four stages of development of the Konin Lakes cooling system.

Table 1

Plant capacity versus lake surface area

Wydajność elektrowni w zależności od powierzchni jeziora

\begin{tabular}{cccc}
\hline \multirow{2}{*}{$\begin{array}{c}\text { Power plant } \\
\text { capacity } \\
\text { MWe }\end{array}$} & $\begin{array}{c}\text { Lake surface } \\
\text { area } \\
\mathrm{km}^{2}\end{array}$ & \multicolumn{2}{c}{ Area/capacity ratio } \\
\cline { 3 - 4 } & & $\mathrm{km}^{2} / \mathrm{MWe}$ & acres/MWe \\
\hline 315 & 2.77 & $8.79 \times 10^{-3}$ & 2.17 \\
583 & 4.23 & $7.26 \times 10^{-3}$ & 1.79 \\
1183 & 8.61 & $7.28 \times 10^{-3}$ & 1.80 \\
1783 & 12.35 & $6.93 \times 10^{-3}$ & 1.71
\end{tabular}

The morphometric characteristics of the Konin Lakes given in tab. 2 indicate that two types of lakes are represented. Gosłwaskie and Pątnowskie Lakes are shallow, moraine lakes; Licheńskie, Ślesińskie, and Wąsowsko-Mikorzyńskie Lakes are deep, valley lakes. The shallow lakes are well mixed throughout the year, while the deep lakes undergo seasonal stratification.

Table 2

Morphometric characteristics of the Konin Lakes Mierzalne parametry Jezior Konińskich

\begin{tabular}{|c|c|c|c|c|c|c|c|}
\hline \multirow[t]{2}{*}{ Lake } & \multirow{2}{*}{$\begin{array}{l}\text { Area } \\
\mathrm{km}^{2}\end{array}$} & \multirow{2}{*}{$\begin{array}{c}\text { Length } \\
\text { km }\end{array}$} & \multicolumn{2}{|c|}{$\begin{array}{l}\text { Width } \\
\mathrm{km}\end{array}$} & \multicolumn{2}{|c|}{$\begin{array}{c}\text { Depth } \\
\mathrm{m}\end{array}$} & \multirow{2}{*}{$\begin{array}{c}\text { Storage } \\
\text { capacity } \\
10^{6} \mathrm{~m}^{3}\end{array}$} \\
\hline & & & $\max$. & av. & $\max$. & av. & \\
\hline Gosławskie (I) & 4.38 & 4.0 & 1.5 & 1.0 & 3.5 & 2.1 & 9.1 \\
\hline Pątnowskie (II) & 2.77 & 3.7 & 1.1 & 0.7 & 5.8 & 2.6 & 7.1 \\
\hline Licheńskie (III) & 1.46 & 5.5 & 0.5 & 0.3 & 13.8 & 5.7 & 8.3 \\
\hline Ślesińskie (IV) & 1.52 & 4.4 & 0.6 & 0.3 & 25.7 & 7.4 & 12.7 \\
\hline Mikorzyńskie (V) & 2.22 & 6.6 & 1.0 & 0.4 & 38.0 & 11.9 & 28.9 \\
\hline
\end{tabular}

\section{RYBNIK COOLING LAKE}

The cooling system for the Rybnik Plant includes a $4.65 \mathrm{~km}^{2}$ impoundment on the Ruda River. As indicated in fig. 4, a diversion structure was constructed in the lake to act as an intake channel. The cooling water is discharged into the main body of the lake. 


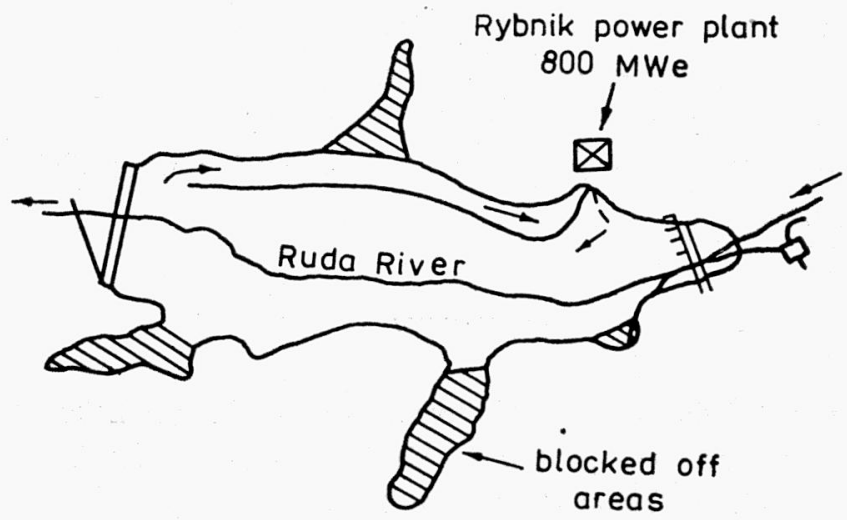

Fig. 4. Cooling lake system for Rybnik Power Plant Rys. 4. System jezior chłodzących Elektrowni Rybnickiej

An active cooling surface area of $4.3 \mathrm{~km}^{2}$ is obtained by blocking off four of the lake embayments where circulation is poor. Table 3 provides additional information on the Rybnik cooling lake.

Parameters of the Rybnik Reservoir Parametry zbiornika Rybnickiego

Total cooling surface area

Active surface area

Total storage capacity

Maximum length of reservoir

Maximum width of reservoir

Maximum depth of reservoir

Mean depth of reservoir

Installed capacity of power plant
$4.65 \mathrm{~km}^{2}$

$4.30 \mathrm{~km}^{2}$

$21.4 \times 10^{6} \mathrm{~m}^{3}$

4. $35 \mathrm{~km}$

$1.5 \mathrm{~km}$

$9.0 \mathrm{~km}$

$4.6 \mathrm{~m}$

$800 \mathrm{MWe}$

\section{COOLING LAKE PERFORMANCE}

For operating cooling lakes, the rate of waste-heat surface exchange can be determined by a simple energy balance, resulting in the following relationship:

$$
K_{w}=\frac{H}{\left[\left(T_{i}+T_{d}\right) / 2-T_{n} A\right.},
$$

where:

$K_{w}$ - waste heat surface exchange coefficient, $\mathrm{kcal} / \mathrm{m}^{2}-\mathrm{hr}-{ }^{\circ} \mathrm{C}$,

$H$ - heat discharged in cooling water, $\mathrm{kcal} / \mathrm{hr}$,

$A$ - cooling lake surface area, $\mathrm{m}^{2}$, 
$T_{i}$ - power plant intake temperature, ${ }^{\circ} \mathrm{C}$,

$T_{d}$ - power plant discharge temperature, ${ }^{\circ} \mathrm{C}$,

$T_{n}$ - natural (or equilibrium) lake temperature, ${ }^{\circ} \mathrm{C}$.

This equation is used to calculate an average heat exchange coefficient over the entire water-body surface.

\subsection{KONIN LAKES}

In order to determine the cooling effectiveness of the Konin Lakes, field studies were conducted. Data were collected in 1969, 1971, 1972, and 1973. For each power plant (i.e. Konin and Pątnów), average daily values of the following parameters were obtained:

power production, MWe,

intake temperature, ${ }^{\circ} \mathrm{C}$,

discharge temperature, ${ }^{\circ} \mathrm{C}$,

cooling water flow rate, $\mathrm{m}^{3} / \mathrm{sec}$.

- In addition, water-temperature data were collected at a number of locations throughout the lake system (fig. 3). Wind-speed data were also collected. Figure 5 provides a graphical representation of the data collected for the Konin Power Plant during the summer of 1971. These data are typical and are presented here to show the variability of various parameters.

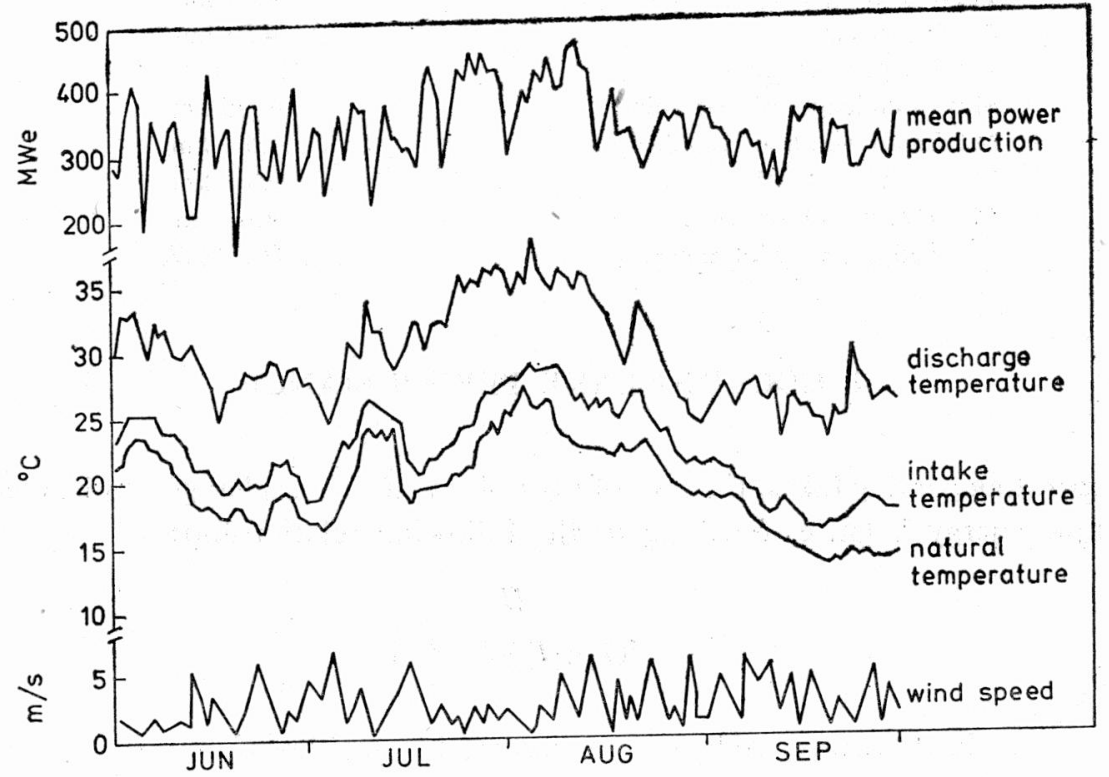

Fig. 5. Average daily cooling system parameters - Konin Power Plant, 1971

Rys. 5. Srednie dzienne parametry systemu chłodzącego Elektrowni Konińskiej, 1971 
Equation (1) was used to calculate surface heat exchange coefficients $K_{w}$ for various meterological conditions over an annual cycle for the Konin Lakes. Values of $H$ were calculated from the power-plant load data using lake aeras $A$ from tab. 2. Intake and dischange temperatures $T_{i}$ and $T_{d}$ were measured. The natural temperature $T_{n}$ was obtained from surface measurements at Gopło Lake, a natural lake situated a few kilometers from the Konin Lakes. Since Gopło Lake is in the same climatic region, it was assumed that its surface temperature would be equivalent to the natural (or unheated) surface temperature of the Konin Lakes. Table 4 summarizes the results of these calculations. Average,

Table 4

Calculated values of $K_{w}$

Wartości $K_{w}$

\begin{tabular}{lccccc}
\hline & \multicolumn{5}{c}{$K_{w}\left(\mathrm{kcal} / \mathrm{m}^{2}-\mathrm{hr}-{ }^{\circ} \mathrm{C}\right)$} \\
\cline { 2 - 5 } & Lakes & av. & min. & max. & S.D. ${ }^{\mathrm{b}}$ \\
\hline Konin Lakes & 15.6 & 12.1 & 21.1 & 2.4 & 22 \\
Gosławskie Lake & 16.2 & 10.2 & 23.6 & 3.5 & 26 \\
Konin Lakes, less & 15.1 & 10.7 & 20.8 & 2.9 & 22 \\
$\quad$ Gosławskie Lake & 16.5 & 12.7 & 20.3 & 1.8 & 34 \\
Rybnik Reservoir & & & & & \\
a - sample standard deviation. & & & &
\end{tabular}

minimum, and maximum values are given, as well as the sample standard deviation S.D. and the sample size $n$. Note that separate calculations were completed for Gosławskie Lake. Since this lake receives the direct discharge from the large Pątnów Plant, it would be expected that its temperature is higher, thus that it dissipates the waste heat at a higher rate; this is confirmed by the higher $K_{w}$ values.

\subsection{RYBNIK RESERVOIR}

Power plant operating data and appropriate meteorological data were also collected for the Rybnik Station. The values of $K_{w}$ were also calculated. For Rybnik, instead of measured natural temperatures, we used calculated equilibrium temperatures. Equilibrium-temperature computations were based on a heat balance of the reservoir under natural meteorological conditions. Reservoir inflows and discharges were also considered. These equilibrium temperatures were compared to actual temperatures measured in the blocked off areas (fig. 4) which were unaffected by the cooling-water discharges. This "verification" process confirmed the general accuracy of the calculated equilibrium temperatures. Table 4 provides the summary statistics for $K_{w}$ for Rybnik Reservoir. 


\subsection{COMPARISON WITH OTHER EMPIRICAL COEFFICIENTS}

The technical literature on temperature prediction contains a number of empirical relationships for calculating heat exchane coefficients (1). EDINGER and GEYER [2] present the general expression:

$$
K=3.2+f_{1}\left(T_{n}\right) f_{2}(W),
$$

where:

$K$ - heat exchange coefficient, $\mathrm{kcal} / \mathrm{m}^{2}-\mathrm{hr}-{ }^{\circ} \mathrm{C}$,

$f_{1}\left(T_{n}\right)$ - empirical function based on natural (or equilibrium) temperature, $T_{n}\left({ }^{\circ} \mathrm{C}\right.$ ), $f_{2}(W)$ - empirical evaporative mass-tranfer function based on wind speed, $W(\mathrm{~m} / \mathrm{s})$. In units consistent with this paper, equation (2) was used to claculate the values of $K$ for four different functions $f_{2}(W)$ for both the Konin Lakes and Rybnik Reservoir. The following average values of $T_{n}$ and $W$ were used:

$\begin{array}{lcc}\text { VARIABLE } & \text { KONIN } & \text { RYBNIK } \\ \bar{W}(\mathrm{~m} / \mathrm{s}) & 3.05 & 1.64 \\ \bar{T}_{n}\left({ }^{\circ} \mathrm{C}\right) & 14.0 & 17.4\end{array}$

Table 5 presents the results of these calculations. The average, minimum, maximum, and $95 \%$ Confidence Interval (CI) for the values of $K_{w}$ determined by the Polish study are also presented.

Comparison of $K$ values

Porównanie wartości $K$

\begin{tabular}{lcc}
\hline & \multicolumn{2}{c}{$K\left(\mathrm{kcal} / \mathrm{m}^{2}-\mathrm{hr}-{ }^{\circ} \mathrm{C}\right)$} \\
\cline { 2 - 3 } Source of $f_{2}(W)$ function & Konin Lakes & Rybnik Reservoir \\
\hline Lake Hefner [2] & 15.9 & 11.1 \\
Lake Colorado City [2] & 22.2 & 15.0 \\
MEYER [2] & 24.8 & 23.4 \\
BRADY et al. [3] & 21.4 & 19.7 \\
& & \\
& POLISH STUDY \\
Average & 15.6 & 16.5 \\
Min., max. & $12.1,21.1$ & $12.7,20.3$ \\
95\% C I & $(10.6-20.6)$ & $(12.8-20.4)$
\end{tabular}

As indicated by tab. 5, the $K_{w}$ for Rybnik Reservoir is consistent with the values calculated by the Lake Colorado City [2] and Brady [3] functions. For the Konin Lakes, the Lake Hefner [2] function matches the measured value. Thus, only the values of $K$ obtained 
by using the Meyer [2] function fall outside the $95 \%$ CI for the values of $K_{w}$ measured on the Polish lakes. Given the range of $K$ values obtained by using the various empirical $f_{2}(W)$ functions, the results reported herein are very representative of and comparable to the past studies.

\section{SUMMARY AND CONCLUSIONS}

Data on power plant operations and meteorology were collected at two power generating/cooling reservoir complexes in Poland. Analyses of the heat transfer from the cooling lakes were conducted. These analyses confirmed that heat transfer coefficients were consistent with the past studies.

The following conclusions were obtained:

1. A complex integrated system of natural lakes (i.e. the Konin Lakes) can be used as cooling reservoirs for steam electric generating stations.

2. The heat transfer performance of such a complex system can be determined from standard field measurements.

3. Data collected on operating power-plant cooling reservoirs confirm the general accuracy of heat-transfer rates developed in past studies.

\section{REFERENCES}

[1] Christianson A. G., Rainwater F. H., Shirazi M. A., Tichenor B. A., Reviewing Environmental Impact Statements - Power Plant Cooling Systems, Engineering Aspects, EPA-600/2-73-016 (NTIS No. PB 228 604), Corvallis, Oregon, October 1973.

[2] Edinger, J. E., GeYer, J. C., Heat Exchange in the Environment, EEI RP No. 49, EEI Publication No. 65-902, New York, Edison Electric Institute, June 1965.

[3] Brady D. K., Graves, W. L., Jr., Geyer, J. C., Surface Heat Exchange at Power Plant Cooling Lakes, EEI RP No. 49, EEI Publication No. 65-901, New York, Edison Electric Institute, November 1969.

\section{WYDAJNOŚĆ JEZIOR CHŁODNICZYCH ELEKTROWNI W POLSCE}

Polski Instytut Meteorologii i Gospodarki Wodnej przeprowadził badania dla wyznaczenia efektywności jezior chłodzących w rozpraszaniu ciepła odlotowego z pary zakładów energetycznych. Badania były prowadzone w dwóch miejscach: 1. kompleksie Jezior Konińskich składających się z 5-ciu jezior o całkowitej powierzchni $12,35 \mathrm{~km}^{2}$, zapewniających chłodzenie dwom elektrowniom o całkowitej wydajności 1783 megawaty, 2. elektrowni Rybnik, która korzysta ze spiętrzenia rzeki Rudy o powierzchni 4,65 $\mathrm{km}^{2}$. Dane meteorologiczne i operacyjne elektrowni zostały zebrane i przeanalizowane, aby wyznaczyć szybkość wymiany ciepła na powierzchni jeziora chłodzącego. W cyklu rocznym szybkość wymiany ciepła w obu miejscowościach wynosiła w przybliżeniu $16 \mathrm{kcal} / \mathrm{m}^{2}$ godz. ${ }^{\circ} \mathrm{C}$. Wartości wyznaczone dla polskich miejscowości są w dobrej zgodności $\mathrm{z}$ danymi w literaturze technicznej. 


\section{WÄRMEABGABE IN K ÜHLSEEN EINIGER POLNISCHER KRAFTWERKE}

Im Rahmen des polnischen Instituts für Meteorologie und Wasserwirtschat (IMGW) untersuchte man den Abkühlverlauf des Wassers in Kühlseen. Die Untersuchungen wurden an zwei Anlagen geführt. Das 5-Seenkomplex von Konin mit einer Gesamtfläche von $12,35 \mathrm{~km}^{2}$ wird von zwei Kraftwerken mit einer Summenkapazität von 1783 MW genutzt. Die Kühlwässer des Kraftwerks von Rybnik, werden in ein Staubecken an der Ruda mit einer Fläche von 4,65 $\mathrm{km}^{2}$ eingeführt. An beiden Orten war die Wärmeabgabe von der Wasseroberfläche im Jahreszyklus nahezu gleich und betrug etwa $16 \mathrm{kcal} / \mathrm{m}^{2} \mathrm{~h}^{\circ} \mathrm{C}$. Diese in Polen festgestellten Werte, stimmen mit den Literaturangaben gut überein.

\section{ПРОИЗВОДИТЕЛЬНОСТЬ ХОЛОДИЛЬНЫХ ОЗЁР ЭЛЕКТРОСТАНЦИЙ В ПОЛЬШЕ}

Польский институт метрологии и водного хозяйства произвёл и́сследования для определения эффективности охлаждающих озёр в рассеянии отработанного тепла из пара электрических установок. Исследования проводились в двух местах: 1) в комплексе Конинских озёр, состоящем из пяти озёр общей площадью 12,35 км², обеспечивающих охлаждение двум электростанциям общей производительности 1783 мегавата, 2) на электростанции Рыбник, которая использует подъём воды реки Руды, площадыю 4,65 км². Метрологические и операционные данные электростанции были собраны и проанализированы для определения скорости теплообмена на поверхности охлаждающего озера. В годовом цикле скорость теплообмена в обоих местах составляла приблизительно 16 ккал/ $\mathrm{M}^{2}{ }^{\circ} \mathrm{C}$. Значения, определённые для вышеотмеченных мест, вполне соответствуют данным по технической литературе. 